\title{
"I'm Trying to be as Honest as I Can:" An Interview with James Baldwin (1969)
}

\author{
Rich Blint Columbia University \\ Nazar Büyüm
}

\begin{abstract}
This is the first English language publication of an interview with James Baldwin (1924-87) conducted by Nazar Büyüm in 1969, Istanbul, Turkey. Deemed too long for conventional publication at the time, the interview re-emerged last year and reveals Baldwin's attitudes about his literary antecedents and influences such as Richard Wright, Langston Hughes, and Countee Cullen; his views concerning the "roles" and "duties" of a writer; his assessment of his critics; his analysis of the power and message of the Nation of Islam; his lament about the corpses that are much of the history and fact of American life; an honest examination of the relationship of poor whites to American blacks; an interrogation of the "sickness" that characterizes Americans' commitment to the fiction and mythology of "race," as well as the perils and seductive nature of American power.
\end{abstract}

Keywords: James Baldwin, unpublished interview, race, American power, Muslims, literary influences

The interview with James Arthur Baldwin (1924-87) that appears below was conducted by Nazar Büyüm in Istanbul in 1969 and has not appeared in English before now. Characterized as too long for conventional publication when first completed, the exchange circulates now as a consequence of memory. Mr. Büyüm, who went on to become a noted publisher and contributes a regular column to Instabul's AGOS Weekly only recalled the existence of the interview last year (it was published in Turkish on the website of Açik Radyo, an Istanbul-based independent radio station in February of 2015) and brought it to my attention as a piece that might appear during The Year of James Baldwin (April 2014-June 2015), a city-wide, multi-disciplinary celebration of the life, work, and legacies of Baldwin on the occasion of his 90th year undertaken in New York City by 
partners Harlem Stage, Columbia University School of the Arts, and New York Live Arts. After careful review and authentication of the manuscript in consultation with the principal editors of the James Baldwin Review, we determined that the inaugural issue of the $J B R$ was the ideal vehicle for the first English language publication of this quintessential Baldwin conversation.

Magdalena Zaborowska's James Baldwin's Turkish Decade (2009) provided Baldwin scholars with a detailed and nuanced account of Baldwin's interrupted decade in Turkey. While the interview below does not shed any additional light on Baldwin's life in Istanbul, it does provide a sense of his concerns and temperament at the close of the 1960s. Revealed here are Baldwin's attitudes about his literary antecedents and influences such as Richard Wright, Langston Hughes, and Countee Cullen; his views concerning the "roles" and "duties" of a writer; his assessment of this critics; his analysis of the power and message of the Nation of Islam; his lament about the "corpses" that are much of the history and fact of American life; an honest examination of the relationship of poor whites to American blacks; an interrogation of the "sickness" that characterizes Americans' commitment to the fiction and mythology of "race," as well as the perils and seductive nature of American power.

The reader will pursue and excavate for herself the richness contained in this nearly forgotten gem from the disparate and still comparatively slim archive of James Baldwin. However, I must highlight a feature of this interview that betrays Baldwin's moral consistency throughout his career. Whatever critical school one subscribes to as it concerns Baldwin's respective achievements in the genres within which he worked, we can be sure that an abiding morality animated his entire oeuvre. At the core of this ethos was the author's concern for not only humanity but for the human spirit being steadily atrophied by impoverished notions about race and identity. As he implores below, "[i]f only they could trust that 'thing', they would be less afraid of being touched, less afraid of loving each other, less afraid of being changed by each other. Life would be different.... Like all poets, like some women and men, like some of us, I am full with the question of how the human being will be put to right."

This plea and call to a kind of spiritual arms remained a constant throughout Baldwin's career and emerges now, for this reader, as a searing reminder of the force and necessity of human connection. Baldwin's lasting concern with the shape and contours of the interior self is a fact that will always be of interest to scholars. His belated, but sadly resonant moral injunction for human beings (particularly Americans) to bridge that nightmare chasm that separates us strikes me as particularly relevant now as the nation struggles to not implode under the pressure of those corpses that keep piling up as a result of the ready use of lethal state force.

As this interview confirms, Baldwin's prophetic witness is not a consequence of his role as a divine seer, but emerges from the imagination of a thinker and writer who understood the operation of American power and discerned the 
fragile, terrified, and historically fractured places that still trouble the nation's idea of itself.

\section{Foreword by Nazar Büyüm}

I met James Baldwin in Istanbul in 1967. I think it was Cevat Çapan who introduced us. Of course, I knew of him: I had read three of his books, Go Tell It On The Mountain, Going To Meet The Man, and Giovanni's Room. From then on, we met frequently, sometimes I dropped into his flat for a drink, but most of the time he came to dinner either to my home or to Bebo's, a close friend and my wife's father.

At the time of the interview, he was very busy rehearsing for Düşenin Dostu, John Herbert's play Fortune and Men's Eyes at Cezzar theatre. He was both very excited and anxious because it was going to be his first direction of a play. He invited me to rehearsals and I was able to go several times. We were all there on the opening night: my wife Jermen, her mother, Silva, Bebo, and myself; well, in fact everyone was there, theatre people, prominent journalists, stage critics, playwrights, renowned members of the society.... The play was rather avant garde and progressive even for Istanbul of the time, and although it created commotion at some scale, it was received very well for the most part, getting extensive reviews the majority of which were in defense of the play and a great many acclaimed it as a huge success. It would have been unthinkable to stage it in Turkey ten years earlier or ten years later. I interviewed James Baldwin on one of the days preceding the opening of the play.

The interview took place at his apartment in one of the more fashionable districts of Istanbul, Ayazpaşa, just off Taksim Square and almost next to the imposing German Consulate. It had a terrace overlooking the Bosphorus, a rather large living area where we sat to talk. That same apartment would also be the venue of a party Baldwin gave a year later just before I had to join the army for the compulsory military service.

The Baldwin I knew was almost at all times restless. It was as if he was expecting something, in anticipation, as if he was late to go somewhere or to do something important, as if he had the weight on his slender shoulders of not having completed even half of what he had set out to do in life, and time was passing in haste. He was very much there with you, but somewhere else at the same time. I remember warmly that he was a little bit more relaxed at our home drinking red wine and talking with me and Jermen who was pregnant with our firstborn, Milena, who a few months later became our doll and the joy of the greater family.

The interview started off on the wrong foot. He was very pressed for time and I was a rookie. My intention was to talk about his books, his writing and black literature, but he was far from it, saying "the last person to be asked about his development as a person and as a writer is that person and that writer. This is an area I know nothing about." And whenever I clumsily tried to revert to 
his writing he would move away from it and talk fervently about the state of humanity at large. Although I realized and was fascinated by his need to speak only about it, because he "was full to the lid," as he said at the closing of the interview, and my knowledge about the condition of black people was far from being in-depth at the time, to say the least, so I hummed and hawed almost all through the interview. I was obliged to humbly thank him for it, for bearing with me and for being generous and forthcoming despite his interviewer having not prepared himself for such a fiery encounter. Perhaps it was because he had to depart (drift away) from the accumulated agony, or perhaps, on the contrary, he was letting go of his rage as if talking to himself in the dark. Whatever the reason, I felt privileged and grateful looking back at it.

After translating, I took the text to Memet Fuat, the famous literary critic and publisher of the Yeni Dergi, the prestigious monthly of the 1960s and 1970s. After reading he said, "It is a good interview but it is too long for Yeni Dergi. I would like to publish it if we decide to feature Baldwin in one of our special editions." Which did not happen. And so I put it aside and forgot about publishing it.

I forgot about the interview so successfully that even when we founded Adam Publishing in 1981, the company becoming a prominent publisher of literature for the next twenty-five years and although Adam had Memet Fuat as chief editor of domestic literature and editor-in-chief of our monthly literary magazine, Adam Sanat, neither he nor I brought back to our minds the Baldwin interview. It was not until I met Phil Jackson, now Milena's spouse, and while talking over several glasses of rakı one evening the subject of Baldwin became the topic of conversation that I mentioned my friendship with him and remembered the interview.

That is how this text surfaced again, after more than 46 years of forgetfulness.

\section{Interview with James Baldwin}

\section{By Nazar Büyüm}

This interview with James Baldwin took place at his apartment one afternoon. On the one hand he was directing a play for the first time in his life, and on the other he was trying to complete the two books he was writing. At the time and especially on that day as we were getting ready to speak, he was saying that he was "in a state of constant tiredness and insufficient sleep," and this was apparent all the time in those days but especially obvious on that same evening as he was restlessly saying, "God, I have yet to make a phone call."

The interview took place when Baldwin was in such a state. The text that follows is the total of our conversation on that day with the exception of a few small and irrelevant omissions. I wanted it to be published in its entirety, and he thought no change was necessary after I subsequently showed him the text. 


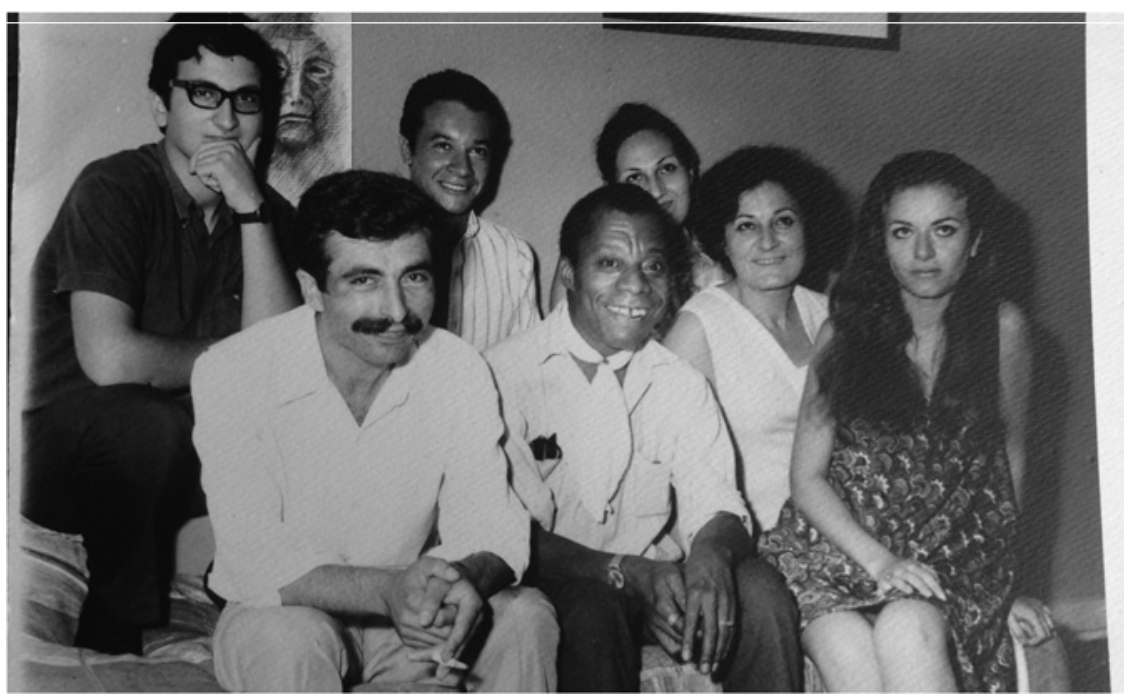

Figure 1 At Nazar Büyüm's in-laws: back l-r-Levon, Jermen's brother; Alain, French writer, JB's friend; Jermen, wife at-the-time; front 1-r-Nazar; James; Silva, Jermen's mom; Vartanuş, niece. (Istanbul, 1967).

BÜYÜM: I would like to learn about you, your life, and about your literary and political views. In as much as a writer's literary and political views are most of the time interwoven, you are at the same time a person very involved in the political activities of the Black American people. On the one hand, you are producing "literary" works and, on the other, you are "one of them." I am therefore hoping that we shall be able to speak about literature and politics as two related but separate topics.

Can we start this interview with a summary of yourself and your work?

BALDWIN: I was born in New York City at Harlem Hospital in 1924. I'm the eldest of nine children. I'll tell you the truth, my own life does not interest me at all. What else can I say? We were born into terrible conditions and somehow we survived ... In fact, the question is not very clear in a way, I don't know how to respond, something about myself?

BÜYÜM: An outline if you can. What did you do, your education...?

BALDWIN: I was not educated.

BÜYÜM: I know you consider yourself not educated, but I want to hear it from you. Then I want you tell me about your work. You write novels and short stories. How many novels so far?

BALDWIN: Go Tell It On The Mountain, Giovanni's Room, Another Country, Tell Me How Long The Train's Been Gone, Going To Meet The Man, Nobody Knows My Name, Notes Of A Native Son, The Fire Next Time, Nothing Personal, how many is it?

BÜYÜM: Nine. 
BALDWIN: Nine books. Then there is Blues For Mr. Charlie, which is a play, The Amen Corner, which is also a play, and I wrote Giovanni's Room as a play.

BÜYÜM: You wrote it again as a play?

BALDWIN: Yes. So how many is it? You see, I'm a difficult person to interview.

BÜYÜM: Don't worry, I'll count it from the tape and let you know. I know from our previous talks that your first short story was published in a church magazine when you were twelve.

BALDWIN: Yes, it was called, "The Massacre."

BÜYÜM: What was it about, do you remember?

BALDWIN: It was about the 1936 Spanish Civil War. I knew nothing about it at the time, all I knew was that people bombed a highway and that was what had grabbed my attention. I must also tell you that the story had undergone some sort of a censorship by the church magazine.

BÜYÜM: You said the year was 1936, didn't you?

BALDWIN: Yes, 1936.

BÜYÜM: That's the beginning of the Spanish Civil War.

BALDWIN: Yes, I know.

BÜYÜM: I think that's very interesting.

BALDWIN: So thought the church, too.

BÜYÜM: [Laughter]You said the story was about the Spanish Civil War. So that we can have a starting point of your development as a writer and as a person, would you like to say a few words about this first story?

BALDWIN: Before answering your question, I must tell you my belief that the last person to be asked about his development as a person and as a writer is that person and that writer. This is an area I know nothing about.

For instance, I don't know why I wrote a short story about the Spanish Civil War, and I'll never know.

BÜYÜM: That was not what I asked, I asked. . .

BALDWIN: No, no, I'm trying to be as honest as I can; and, also, I said I was not in my best form. Furthermore, you are making me ask [questions] that I have not asked myself for a long time.

BÜYÜM: And that requires energy.

BALDWIN: I don't care about the energy, but, that story for instance, now looking back: I'm now forty-five, I was then twelve. It was thirty-three years ago, wasn't it?

BÜYÜM: Yes.

BALDWIN: That is an extraordinary beginning of an extraordinary life in art. Because, I could've written about something else, couldn't I? Wouldn't I be expected to write about something else?

BÜYÜM: Yes, I guess you would be.

BALDWIN: Why would a twelve-year-old boy write about the Spanish Civil War?

BÜYÜM: True, why? Extraordinary.

BALDWIN: I am not saying this to brag. I am saying it as a puzzle.

BÜYÜM: I understand. I know readers in Turkey know about your more recent work, so by asking that question I wanted. . .

BALDWIN: No, no, I don't mind, I don't mind what you ask me. But, in order to respond to your questions I must try to tell the truth, and that makes me ask questions to myself, you see?

BÜYÜM: Yes, I can understand that. 
BALDWIN: I don't want to mislead you.

BÜYÜM: Thank you. Now, this next question you may find absurd and simple, but I want to ask it: what made you write? Something from above, some urge is sometimes extended as the reason to start writing, and sometimes people say there was nothing else to do. So...?

BALDWIN: I think they would not write if that was the case.

BÜYÜM: Your writing for instance, your starting to write, did it follow a conscious aim?

BALDWIN: I wrote because I could. I wrote because I could spell. I remember at school I could write correctly a word when I heard it and before I saw it. For example, I knew that in the word "donkey" (for some reason I only remember this word, but I was so little) I knew there was an "e." A person could rightfully write it as "donky," without an "e," but I knew there was an "e" somewhere. I never learned grammar. I wouldn't know what is wrong with a sentence, but I can put it right. I do not know about the rules of making a sentence, but I can tell a good sentence from a bad one.

BÜYÜM: Yes, of course.

BALDWIN: What made me write is something I'll never know. On the other hand, when I became of age, what compelled me to write was because I could not do anything else. I wasn't prepared to be a salesman-I was a salesman for a time. I wasn't prepared to be a waiter-I was a waiter for a period. I wasn't prepared to do heavy work-I did a lot of heavy work. It was a hard but necessary matter of saving myself and my family.

BÜYÜM: So, perhaps the conditions and your...

BALDWIN: ... my reaction to those conditions.

BÜYÜM: Yes. Now, I had asked you this before. As far as I know there were no black American writers who were so widely read as to influence you. Are there in your writing traces of any such influence in form or in content?

BALDWIN: No. By the time I learned that there were black writers I was already a grown up person. There is no writer that I knew as I was growing. In fact, there were two writers that I knew, Countee Cullen, who was a poet and taught me French at school, and Langston Hughes. I was to know Langston Hughes much later when I myself was also a known writer. And then there was Richard Wright, and he was the more important person for me, but not as a writer. He was important for me because he was proof that a black person could also be a writer. Because it was laughable for someone of my standing to walk up and down in Harlem saying he would be a writer. No one believed me, not my father, nor my mother, and the kids were just kids. So, Richard Wright is for this reason very important for me, but not as a writer. The only black writer who has really influenced me (this will be misinterpreted, I know, but it is not my fault, it is the way I was educated) and who I had read much much later and who had a sense of history and a sense of style was W. E. B. Du Bois. Du Bois was not a good novelist, but he had real intelligence, an investigative intelligence; and for these his country awarded him with exile in his own country and death in Africa. Americans would say that he exiled himself, but that is not so. I want to say it loud and clear. He was thrown out of his own country by his own countrymen and died at the age of ninety-four, just one day before the March on Washington. 
Outside of this, no one of my generation knew any black writers. For instance, I did not know that Alexander Pushkin was a Negro writer simply because in American schools Negro children are not taught that, and the reason why they are not taught that is this: if you begin getting to know yourself in that manner, they cannot exploit you any more. Had I believed in what the Americans had taught me, had I believed that I was a savage who should feel gratitude to Christians, who had just lost his tail and come out of being a monkey, someone who had had no contribution to civilization, whose history has not even been a series of catastrophes, someone who has no mention in time, a savage not worthy enough to have a history, then, only then I would either be dead, or an addict, or in jail simply because I had believed in what they said, just like many of my generation who were bound to the morphine needle or who were jailed simply because they believed what they were told. This is not a crime that I accuse only my country of, this is a crime that I accuse all of humankind. It is a serious accusation.

BÜYÜM: It is indeed. Now, Jimmy, if we were to study the black American literature vis-a-vis black African literature in general from a roots point of view, do you think there are ties between these two in terms of form and/or content?

BALDWIN: A difficult question to answer. Because first of all both African poets and Afro-American poets are of a tradition that does not exist in the West any more. For example as a writer I don't come from a written tradition. My background is from an oral, verbal literature. In Africa we did not write down the blues, we talked. To talk-western nations should keep in mind talking as a possibility and an opportunity. Everything passed from father to son in this way. It is in this way that both the tribe and the state were able to continue to exist. It was thanks to the same reason that it was possible for the American Negro to survive.

BÜYÜM: So we owe this to the oral literary tradition.

BALDWIN: Yes. In America we have to talk in a way that as a white person you would not understand. Ray Charles still speaks in a manner that whites do not understand. I had to tell my brother, to warn him in a time span of three minutes under the watchful eyes of the slave guard what would happen if he did not do this or that. My brother had to let me know he was going someplace and warn me. "Steal Away To Jesus" was thus created. It is still a private language. Private for two reasons: because we are still in the same condition: the country does not belong to us; and we do not have power. Greenwich time is based on an English invention; but there is another called "Negro time," there is another life that does not exist in London.

BÜYÜM: Yes, I think I understand. I have yet another question about the African and Afro-American literatures. [Jean-Paul] Sartre says that the African poetry is the most revolutionary poetry of the twentieth century. Do you think this is also true for the Afro-American poetry?

BALDWIN: There is some distance between the revolution and the poet. I gradually came to understand that Sartre who is a respected person is not an authority on any kind of revolution. He cannot be. In my view, in fact, Sartre knows nothing about French poetry; his knowledge about black poetry is even less. Negros exist in [the] white man's mind primarily as a hope and as a symbol; all this black-white 
segregation and black-white clash created by the white man's becoming powerful and the manner by which he acquired strength has left a dreadful sentimentality in every white person's mind. Being Jean-Paul Sartre and living in Paris and becoming Richard Wright's friend and to manipulate thoughts everlastingly about people below you is one thing; and being Martin Luther King or Malcolm X [is] an entirely different matter. The difference is that Malcolm X is not sentimental about the people he represents. He is one of them. When Malcolm spoke about whom he represented his starting point was not some theory, his starting point was his life and the life of the people he represented. It is this that explains why he was so effective on people he addressed and why he was dangerous. Dangerous for the existing order.

BÜYÜM: Going back to your work, you mainly employ novel, short story, play and essay forms. How is the decision made? Do you find that one topic is more suitable for a novel while another subject should be treated in a play? How does that happen?

BALDWIN: I cannot answer that. Something comes to my mind; and that something has always come with its form and style until now. Sometimes I was mistaken. The Amen Corner started as a short story in 1951 or 1952, no, in 1951; and then I realized it was not a short story, it was a play and there was nothing I could do about it. I did not know whether or not I could write a play, but it could not be a short story, it was a play.

BÜYÜM: It was your first play, wasn't it?

BALDWIN: Yes, it was. Another Country was always a novel. I don't know why. The Fire Next Time was always an essay.

BÜYÜM: In your writing there are passages reflecting naked, rough, tough, painful, concrete reality alongside with what we may call "emotional prose." Your work is therefore described as realistic with a romantic tinge sometimes.

BALDWIN: Ooooo!

BÜYÜM: When I say this I believe I am conveying a rather widespread perception. BALDWIN: And you are conveying it very politely.

BÜYÜM: Not at all. As you well know...

BALDWIN: Go ahead [laughter]. Continue.

BÜYÜM: All I'm saying. . .

BALDWIN: I know my fame.

BÜYÜM: Well, do you think that is true? And, in that context, how would you classify your work from a literary schools point of view?

BALDWIN: Tch, tch, tch [No, no, no]. I would not classify my work from a literary schools point of view.

BÜYÜM: What would you say about your work from a literary schools point of view?

BALDWIN: I did the best I could, considering my limitations and my abilities. So far as I know I do not belong to any specific school or literary current. It is certain that I do not belong to any of [the] main currents that is evident in most of what I read. I tried to keep away as much as I could. I may be a romantic but I tried to keep away from being sentimental as much as I could. Whatever I was looking at I tried to look right in the eye; I'm not saying that I succeeded, but it is my passion, it is what I try to do: to tell the truth. I know very well that no one tells the truth at all times. But a person can at least refrain from consciously telling lies. 
BÜYÜM: Yes, of course. I understand what you are saying. Something else comes to mind: you may not categorize your work or may not be able to, but that would be the main starting point of critics of your work. They do that, that's what they do.

BALDWIN: Let them.

BÜYÜM: OK. But still. . .

BALDWIN: I'll outlive all of my critics. Something else, I do not have many critics, I have those who evaluate. And that is not the same thing.

BÜYÜM: No, it is not.

Since literature has a function, or functions, it must have a duty, or duties. What do you think those duties are, Jimmy? Also, from a literary perspective in general and your work in particular, how should an author carry out those duties? Up until now we treated this in an indirect manner. Could we now address it directly?

BALDWIN: You say functions and duties, I say cause and effect. What I want to say for instance is that, what a person should first realize, what I should first realize is that I am not Mao Tse-tung, Fidel Castro, or even Eldridge Cleaver; and I am not Malcolm X or Martin Luther King. First of all, I must accept that my function and my duty is summarized in the reality of my being a writer. I can do this better than managing a march or writing a slogan. With respect to the terrible conditions I was born into and I am producing in, my primary role and function is to witness this state and record it. To do this requires trust in the efficiency of humankind; so that, when the fight is over, a boy like me, in my youth, or a girl like my sister, in her youth, can find something they need outside of slogans and flags and programs: the belief in the human soul, which is the only thing that can really change the world. It is nothing else that changes the world. This is true from the point of view of one's own time, one's own function and one's own duty; and it is true of one's own causes and effects. Some people think that I am responsible for the burning of towns because I wrote The Fire Next Time. I wrote The Fire Next Time so that towns would not get burnt. It is for this reason that one of the responsibilities, my responsibility, for instance, is not to my generation but to the new generation. The responsibility of a poet is to empower the society that has produced him to create new poets like him. And that is a political function, as Ronald Reagan and Richard Nixon know well.

BÜYÜM: Does that mean that to talk to the coming new generation, to give them something to relate to, is more important than communicating messages to your own time?

BALDWIN: What is written is not for the people to read in the future. For what is written will be there whether it is read or not. A society changes in very mysterious ways. Malcolm changed millions of people he had never met and who did not know they were changed by him. The reason why a society respects the poets, respects those poets they have stoned, they have made starve, is because they know and they feel that it is poets who are their only hope. [Poets are] being described in a manner that they cannot be tolerated on the one hand; and on the other [hand they are] the only hope they have to live with.

BÜYÜM: This is a fresh and refreshing explanation of the reactions and the exasperations of the modern societies in the West.

Jimmy, in times past and present we know there are both foreign and American white writers who wrote about blacks. And on the other hand, we have black 
American writers. While white writers are obviously writing about blacks, blacks are writing about themselves.

BALDWIN: Do you think that is so?

BÜYÜM: Isn't it obvious?

BALDWIN: You do not recognize a black person from the color of his skin, or a white person, you cannot recognize him either. I would like to subscribe to that view, but I know how hard it is to reach somewhere beyond vengeance and fantasy. So, from my point of view, white and black alike, most of the American writers are dealing with fantasy. This exists in a different way in a Negro's mind, and differently in a white person's mind, but it still is a fantasy. No writer I can think of as of now-I am talking about novelists, of course, because this is not true for some essayists, for some writers it is also not true. I can give you names, but if I did I would leave such people out that I'll get myself into trouble, so it is better if I did not mention names-I can think of no writer who has attacked the economic foundation-because there is an economic foundation of the oppression; no one has even attempted to. Every single one of the liberals want to be forgiven simply for the truth that they make money from black [men]. The Western world is based on this. Everything is loaded on the black back of a Negro miner in Johannesburg, South Africa. South Africa, the government of which cannot survive for an hour without the backing of whatever is left that can be called the West (and by this I mean Washington D.C.). Everyone knows this, but no one says anything about it.

BÜYÜM: What you are saying is that they may have different thoughts inside their heads, but most of those writers are dealing with fantasies?

BALDWIN: It is not important what you have in your mind. It is what you do that matters.

BÜYÜM: So, in your view, the product is fantasy?

BALDWIN: For the most part. On the other hand, it is of course difficult to attack the society you depend on. It is very difficult, almost impossible, for a person to scrutinize his own history and try to change it, very few people have been able to do that. [James] Joyce was right when he said that history was a nightmare he tried to wake up from.

BÜYÜM: So far you have talked about the black movement in America in a somewhat indirect manner. Could we now speak about it directly?

BALDWIN: No writer talks about something like that directly. Directly ... in a straightforward manner ... [Dwight]Eisenhower spoke directly, Nixon speaks directly, Hitler was direct. No artist at no time speaks directly about such a matter. Because what you will talk about, your subject matter, is extremely slippery, wild, so for a person to approach his subject matter which is the state of humanity, his roots of approach have to be extraordinarily indirect. If it wasn't for this, no one all over the world would ever hear talk about a single artist. And the subject is how and in what manner the human being, you, me, all of us are responsible for the catastrophes we so despise and complain about.

BÜYÜM: OK. But still I'll ask you to tell me about the black movement in the U.S. BALDWIN: There is no black movement in the U.S., there is white movement there. BÜYÜM: Can you repeat what you just said? 
BALDWIN: There is no black movement in the U.S. I know, it looks as if there is one. There is a white movement in the U.S. and a black reaction against it. It will be better understood, what I really want to say ... if we left alone the terms white and black and talked instead about Christians and Jews, for instance, or Germans and Jews, or Czechs and Russians. You cannot describe what has happened as a Czech movement, can you? What has happened is a Czech reaction to Russian oppression, isn't it? You cannot call what happened after they bombed and killed children at Sunday School a black movement; it was simply a manifestation of white power. Like all societies, the white society is also determined to protect themselves. Isn't that right?

BÜYÜM: Right. Please go on.

BALDWIN: So, the white movement in the United States is the endeavor of a people to survive: but an effort within principles which have no validity any more. Nixon is not a Negro, and Negroes did not vote him into power.

BÜYÜM: That is so true. There is something else that I recall. You had told me once that you did not like the word "freedom," that you preferred to use "liberty" instead. Can you explain why?

BALDWIN: Because I worked with many black students; in order to be able to speak about "freedom" which is a political and, as I said before, an economic problem, man should first be liberated or liberate himself from oppression. After that, when the best of all possible worlds is in their hands people can decide whether they want to be "free" or not. But before being liberated from slavery, the problem of "freedom" is purely academic. For example, the problem of democracy in an underdeveloped country-I use the word as a Western term to specify a country's economic wealth-before you can start to handle the democracy problem ... what relevance would elections have in Vietnam? What relevance do elections have in America, for that matter? Am I making myself clear?

BÜYÜM: Yes, you do. From the standpoint of whites and blacks the situation in America is usually defined as a "social" problem, whereas you maintain that it is not. How do you define this condition and why?

BALDWIN: I think that it is a psychosis. European immigrants and immigrants not European who found themselves in California, who found themselves crossing the Rocky Mountains, people who found themselves in unbelievable conditions had to be loyal to their ancestors because they had nothing else to relate to. That is the reason why there is a St Patrick's Day in America; there was a German American Bund for the same reason and we still have an American Nazi party. Every person in America-what I am about to say is a reality of America, a truth which demonstrates that the melting pot is a total lie-everyone, regardless of where he is from, Polish, Italian, Jewish, every person regards a different history as his own. They pride themselves with American history, but still they relate to another, a different history and even adapt to and live with it. With this perspective, the Negro who came to America without a history, the Negro as an indispensable economical mule, built the country and then became the most unwanted person in that country. Because those who create victims know what they are doing. They pretend they don't, but they always know what they are doing. That tiny republic striving to exist, how could it reconcile and live in harmony with the natives who spoke none of the known languages and who had not heard anything about God, and with the 
Negroes who seemed mystifying purely because of their color, who were used as animals but slept with like human beings? These people knocked up Negro girls, and then they lynched their children fully aware that they were their own. I know someone in Alabama, a very light skinned Negro. His father is a very rich and famous lawyer. This man goes to his father's office every day, sits in the waiting room for ten, fifteen minutes, half an hour, just to irritate his father who has not recognized him as his son. There is no doubt that this person, this man who goes to that office every day is in terrible trouble. But what he does is not something incomprehensible: that lawyer is his father.

BÜYÜM: If we employ the Marxist terminology, is it possible to approach the problem of ethnic discrimination from a classes point of view? This question brings to mind a second: what class of the whites in America is more active in the black-white clash? I'll ask you to keep in mind the following two points: my question is, which class of whites are most actively with and which class against the black in this struggle?

BALDWIN: Let us forget Marx for one moment. The poor white of the South is pitiable because he thinks he is superior to the Negro. He thinks in this way because those who have made him tied to this thought through generations have said so. He is anxious about his wife-another psychosis-he is anxious about his job, he is anxious about his children, in fact his anxiety is about what it means to be white. And when all these come together, one's fear of his sexuality, one's fear of his power, one's fear of not being able to earn a living, when all these come together the end result is what is called racial segregation. A short while ago a boy of eight-I think he was six, but in any case not more than eight-was put in jail for sexual assault for kissing a white girl. It was a very popular case, it was called "The Kissing Case." Since democracy is democracy and rage is rage, the boy was released in the end, but he was arrested and put in jail. There is something very important: in my view we should observe America as an example. It would be wrong to think that this is not taking place elsewhere, because the words we employ are "white" and "black;" this thing is taking place everywhere, all around us. Human beings are capable of always finding a reason to destroy another human being. Black, white, green, blond, brunette, circumcised, uncircumcised. The human being has always been a master in this art. They always come up with the most magnificent of reasons to kill each other. The stage that the world has come to today is such that it involves and interests all of us. It is for this reason that we were able to drop the bomb some 25 years ago, whereas although everyone has it now, no one dares to use it. It is not possible any longer to destroy part of the humankind without annihilating all, and that is our only hope. But humans have tried to destroy themselves before, and they can do so now.

BÜYÜM: You mentioned that the poor white of the South has the worst attitude against the blacks, because they were taught so.

BALDWIN: They find themselves personified in our President who is a pathetic white: this is the simplest definition of poor white and the most evident meaning of the Horatio Alger legend. It is a terrible thing for a sovereign people to elect a second-hand car salesman to be their president ... But, when you want to talk about the poor whites or try to understand them, just look into their faces and listen to their speech. 
BÜYÜM: Whose?

BALDWIN: My president, for instance, and yours.

BÜYÜM: Yes, thank you, James. My questions demonstrates my ignorance. But I'm trying to learn and to understand. In the series of American presidents...

BALDWIN: ... there are quite a few corpses.

BÜYÜM: Did not hear you?

BALDWIN: Quite a few corpses...

BÜYÜM: Quite a few corpses?

BALDWIN: And many more in jail.

BÜYÜM: And many more in jail ... And quite a few exiles?

BALDWIN: Quite a few exiles.

BÜYÜM: And if we dared to count, Martin Luther King, [Ralph] Abernathy...

BALDWIN: I have a longer list than you can ever have.

BÜYÜM: I am sure you do. And you should. I will only name a few of those I know. In the list of black American leaders there is Martin Luther King, Abernathy, Malcolm X, Stokely Carmicheal, among others. This line brings to mind a conversion from the religious to unreligious. Furthermore...

BALDWIN: It all depends entirely on the point of view. The church was the only meeting and convening venue for the American Negroes and all the Negroes that you know, from Ray Charles to Abernathy to Martin Luther King, to Malcolm X, to me, all Negroes have come from that forum, from that church. We learned everything we know there. That means, we learned to read, we learned secretly reading the Bible there.

BÜYÜM: You say reading the Bible secretly. Why so?

BALDWIN: It was forbidden.

BÜYÜM: Why?

BALDWIN: No one wants his slave to learn how to read.

BÜYÜM: It was therefore not reading the Bible, but learning how to read that what was important?

BALDWIN: And the Bible also, on the other hand. White Americans thought it was their duty to save the souls of their slaves. They were therefore reading them the Bible, sections of the Bible from St Paul, for instance, saying "Slaves, obey your masters." But it was obvious that when the slave started reading the Bible, he would read its other sections, and read other books as well. And that is what he did. The slave, or more specifically, his soul, should be saved, and the Bible was therefore needed. In the beginning there was what was called the "Congo Square" where the slaves where allowed to convene and pray under their masters' guns.

BÜYÜM: Where was this?

BALDWIN: In Louisiana, I think, but I'm not sure. Where it was is not that important, they were in many places, they were called the "Congo Square;" the slaves did what we call today "their thing" at these places: they wept, shouted, sang, and prayed. But they were always surrounded by their masters, and their masters had guns.

So, that is how we learned what we learned. This is one page of history that will never be torn and discarded. What I am telling you is the truth; and they will lose nothing from being the truth even if I did not tell them.

BÜYÜM: It is evident, therefore, that the reaction of blacks has changed dramatically over time. 
BALDWIN: A book will come out next month by Alex Haley, who had written The Autobiography of Malcolm X. Haley, who is a Negro in the eyes of the law and its application, traced his roots to a village in Africa. He found the ship in which his ancestors had crossed the Atlantic; his ancestral line took him to Paris, to Dublin, and to quite a few white families in America. Someone defined the black problem in America very well: Walter Hines Page said, "The Negro in America is a kind of madness that manifests itself in white people." Malcolm when he found himself in Mecca and realized that "black" is not a color but a state of mind voiced this in a different way; the English are slowly realizing this, so are the French. You Turks should also keep it in mind.

BÜYÜM: We are learning to keep in mind some things.

Jimmy, in your view do the reactions of Negroes in America have political coherence as a whole?

BALDWIN: Do you think any nation who have lost their sovereignty can have any coherent activity? Can I talk about politics without talking about power?

BÜYÜM: My question is not about the general state of politics in America, I'm asking about the activities of the blacks.

BALDWIN: I should ask that question to you. There is heard the thunder of a revolution in what's going on between blacks and whites in America. If you kill the leaders, send some into exile and put into jail the remaining, you will be forcing the whole energy to accumulate underground; you'll be doing something else and that something else will be the most dangerous thing a power can do: those who do not have awareness suddenly realize that what is happening on the other side of the city is in fact happening to them, is their own. The black students who started the Civil Rights movement for instance are all twenty years younger, at least twenty years younger than me and all belong to the class we call "The Black Bourgeoisie." These sons and these daughters sat on the ground for a bitter cup of coffee. They went to jail, they received blows on the head, they were spitted on. How do you think what happened affected their parents? It is exactly the same thing as the white boys beaten mercilessly at the last Democratic Party Congress in Chicago. It does something to everybody ... it changes everything. It may take a while for the change to be visible. But nobody wants his children to be beaten, to be jailed, and for nothing, without any reason. What the oppressors always do turns the people against them in the end. When a government goes against the true will and loses the support of the people, it does not matter if it reigns for a thousand years for those who know it will fall. This is what is happening in South Africa. This is what is happening in Angola. This is what is happening with the people we call "Negroes." And the same thing will be happening elsewhere as well. Vietnam is proof.

BÜYÜM: You said "The Black Bourgeoisie." It is the first time I am hearing the term. Can you explain?

BALDWIN: This was a class of the American blacks, the American Negroes. The term changed by each generation ... Malcolm explained this very well: there was the house Negro and there was the field Negro. The field Negro toiled the field, did all sorts of hard and heavy work. And the house Negro worked in houses. They had clothing and they served their masters. Rudyard Kipling has a great poem about this, "Gunga Din." What happened in the twentieth century did in 
fact happen in 1956. This class disappeared. The Black Bourgeoisie was the president of an old Negro college, for example, he went to Mr Charlie to ask for a desk, or for a bed - and he got what he wanted. Booker T. Washington was the first of these, the price of what they got was the good conduct of the black masses. "I will give you what you want if you keep those dirty niggers quiet." When the Supreme Court banished the segregation act (this is not yet put to force), the raison d'etre of this class ended exactly like the raison d'etre of the British blacks ended for Britain, and for the same reason: you had nothing any more that you could bargain for as a college president. You could no longer guarantee that the blacks around would remain silent and keep quiet. They were nervous, and they were not satisfied by putting me out of work, they forced me to go to jail and pay bail. They forced me to understand that the mortgaged house that I had bought at a very high price did not in fact belong to me. The name of the game is power.

On the other hand, the Black Bourgeoisie had always been an invented bourgeoisie, because they had no power. In fact, this is nothing but a simple imitation, because everywhere in the world the bourgeoisie ruled with a power that they did not understand and did not dare to attack: that is, until it became a matter of life or death. Not even then they understood power. They do not understand why banks go bust and their savings flow into the pockets of pirates, why the cities become impossible to live in, why they buy a car every year or why their color TV can cause cancer.

BÜYÜM: What was that again?

BALDWIN: The American government had to confirm that the color TV sets could be dangerous, that they produce radiation and that people could die of that. The name of the game is profit.

BÜYÜM: So we have two words now, power and profit. I have two more questions for you, Jim. Let me ask you both at the same time, for perhaps you choose to answer them jointly. What is the position of the Black Muslim movement vis-a-vis the general black reaction? And the second and last question is perhaps the most important: is there anything else you would like to tell me about?

BALDWIN: [Laughter]

The Black Muslim movement as it is today... The most interesting aspect of the Black Muslim movement is that it gathered momentum in prison. Millions of people became Muslims in prison. Our young black people in prison-and I know how young black people were jailed and why, and I know how long they were kept there and why-they heard a message they desperately needed: they heard the voice of a Black Moses from the Mountain in the Desert saying that they were victims and therefore chosen by God, and that God was black, not white. It is a very easy claim to own God. All the Western countries gained power and murdered millions and millions and millions of people by this same simple principle. Therefore, when you hear that God is black, everything changes completely; and you begin to anticipate patiently the day the sword will be in your hands. It was as religious a movement just as much as the Catholic Church, and was dangerous for the same reason. Malcolm was the only survivor and the saint of the movement; he abandoned it and was killed.

It is a terrible thing to say to your child not to speak to another child because his skin is black or white. What happened to Martin Luther King was one of the most terrible things that could happen to a father in a lifetime: Martin had to 
explain to his son who was three or four at the time why he could not pee in the toilet of a gas station on the highway. Such a thing leaves a horrible mark on a child's life, and worse on the father's. And thus is created theology, all theologies. Such a thing is made possible because the poor white who elects Nixon and whom Nixon elects-both are the same thing-feels secure somehow if a black child does not urinate in his white toilet. It is a sickness.

BÜYÜM: What kind of a sickness is it?

BALDWIN: You ask me what kind of a sickness it is? Among other things it is a sickness of habit. There are aspects of it that may take us to topics we cannot cover tonight, in one night. It has one aspect, for instance, to do with a segregation that was created when Christianity gained power in the world; people, because they were smart, believed that the Virgin Mary gave birth to a son, and furthermore, that son had the kindness to die for all humankind; this is a legend that is alive all around the world, of course, but it was not named as Christianity yet and Christianity did not yet have the warships to prove what it preached and make the whole world accept its point of view. But everyone knows that a woman does not become pregnant because a Holy Spirit comes and whispers in her ear. I'm curious about Joseph; he was probably the first Negro.

BÜYÜM: [Laughter] What you mean is more clear now, with Joseph being the first Negro. How about the last question?

BALDWIN: Anything else I want to say?

BÜYÜM: In Turkey and to me.

BALDWIN: In Turkey and to you... We could as well be on the Moon. I am full to the lid... I have a curious dilemma, because perhaps I do not like some people, although even that is very rare. I am not capable of not liking people; I am much more intelligent than I look and I know a lot more than what I say, but I really like people. I like people because I think that they have something; yes they do, I know they do. They have something they don't trust. If only they could trust that "thing," they would be less afraid of being touched, less afraid of loving each other, less afraid of being changed by each other. Life would be different. Our children would not be victims that they are now, we would not be either. But for some reason love is the most frightful thing; something that the human being is most in need of and dreads most. I do not know why ... Ibsen wrote a play called Ghosts about this and we all are still in that play which was written a hundred years ago. Like all poets, like some women and men, like some of us, I am full with the question of how the human being will be put to right. You know, it is for this reason that all this black, white, Armenian, Turkish, Greek, Jewish, etc., etc., etc., never carried any meaning for me. The question is how to fix ourselves. Give birth to ourselves. To make us live free of all these swaddling clothes, free of all these habits. These gradually take us to Dachau, to Genocides, and turn our daily life into a desert hard to define.

The lives of the bankers, the lives of the advertising people, the lives of people who surrender their lives to material objects.

I can not answer your question... 


\section{Contributors' Biographies}

Rich Blint is Associate Director of Columbia University School of the Arts Office of Community Outreach and Education, and Research Affiliate and Adjunct Assistant Professor in the Institute for Research in African-American Studies at Columbia. He is coeditor (with Douglas Field) of a special issue of African American Review on James Baldwin (Winter 2013); contributing editor of The James Baldwin Review; co-curator (with Ian Cofre) of the exhibition Bigger Than Shadows; and curator of the exhibition series built environments, an initiative conceived to engage contemporary issues in fine art concerning aesthetics, value, difference, and public space. Rich earned his $\mathrm{PhD}$ in the Program in American Studies at NYU. He is currently at work on his book manuscript, "Trembling on the Edge of Confession: James Baldwin and Racial Iconicity in Modern American Culture." He sits on the boards of Vanderbilt University's Issues in Critical Investigation: The African Diaspora, and CLAGS: The Center for LGBQT Studies at the Graduate and University Center, CUNY.

Nazar Büyüm, born in 1944, studied English language and literature. He was Head of Creative at Manajans J. W. Thomson between 1972 and 1975. In 1975 he founded Ajans Ada with two partners which quickly became one of the top three advertising agencies in Turkey. He left Ajans Ada in 1980 and started two separate publishing companies, Adam Yayınları, which developed to be the largest publisher of foreign and domestic literature, Anadolu Yayıncilık, publisher of reference works, alongside with an advertising agency, Merkez Ajans. In 1986 he founded Ana Yayıncilik, a company established to publish AnaBritannica, the Turkish language Encyclopedia Britannica, which became number one source of reference in Turkey. He lives in Şile, a small town on the Black Sea coast. He writes a column in the AGOS weekly. He has two daughters, Milena and Ludmilla, a son, Ali Murad, and a grandson, Cuba. 